\title{
Biology and Management of Dodder (Cuscuta spp.) in Ornamental Crop Production and Landscapes ${ }^{1}$
}

\author{
Kaley Mierek, Chris Marble, Nathan Boyd, and Shawn Steed ${ }^{2}$
}

\section{Introduction}

Dodder are a group of over 150 species in the genus Cuscuta. Dodder is a leafless, parasitic weed that relies on its host for survival. These species have a wide variety of host plants, including landscape and nursery grown ornamentals. This EDIS publication was developed to help commercial growers, landscape professionals, and homeowners identify and manage dodder infestations in their greenhouses, nurseries, or landscapes.

\section{Species Description}

\section{Family}

Convolvulaceae (morning glory family)

\section{Other Common Names}

Strangle weed, hairweed, hellbine, angel's hair

\section{Life Span}

Dodder is classified as a summer annual. Upon germination in the spring or summer, seedlings have approximately 5 to 10 days to attach themselves to a nearby host plant. If they do not find a suitable host within this time, the seedlings will die, as they depend upon the host for survival.

\section{Habitat}

Dodder is a parasitic plant that has a wide variety of host plants, including agricultural crops, ornamentals, weeds, and other plants. Dodder can be found in agricultural crops, fields, woodlands, landscapes, and other locations where suitable hosts are growing.

\section{Distribution}

There are over 150 species of the Cuscuta genus distributed throughout the world. Most of the species are found primarily in the Americas, from Canada to South America, but certain species also occur in Europe and Asia. Ten species have been verified in Florida (Holm, Doll, Holm, Panch, \& Herberger, 1997; Lanini \& Kogan, 2005; Wunderlin, Franck, \& Essig, 2017).

\section{Growth Habit}

Seedlings germinate and emerge from the soil and begin to coil around a host plant. They have a vining growth habit and grow in a counter-clockwise direction. Once a seedling attaches to a host plant, it will support its own weight by forming multiple attachments with the host or adjacent plants nearby (Figure 1). Once fully established, thick mats of dodder stems can completely cover a host plant (Lanini, Cudney, Miyao, \& Hembree, 2010) (Figure 2).

1. This document is ENH1292, one of a series of the Environmental Horticulture Department, UF/IFAS Extension. Original publication date May 2018. Visit the EDIS website at http://edis.ifas.ufl.edu.

2. Kaley Mierek, former research assistant, UF/IFAS Mid-Florida Research and Education Center; Chris Marble, assistant professor, Environmental Horticulture Department; Nathan Boyd, associate professor, Horticultural Sciences Department; and Shawn Steed, multi-county environmental horticulture production agent II, UF/IFAS Extension Hillsborough County; UF/IFAS Extension, Gainesville, FL 32611. 


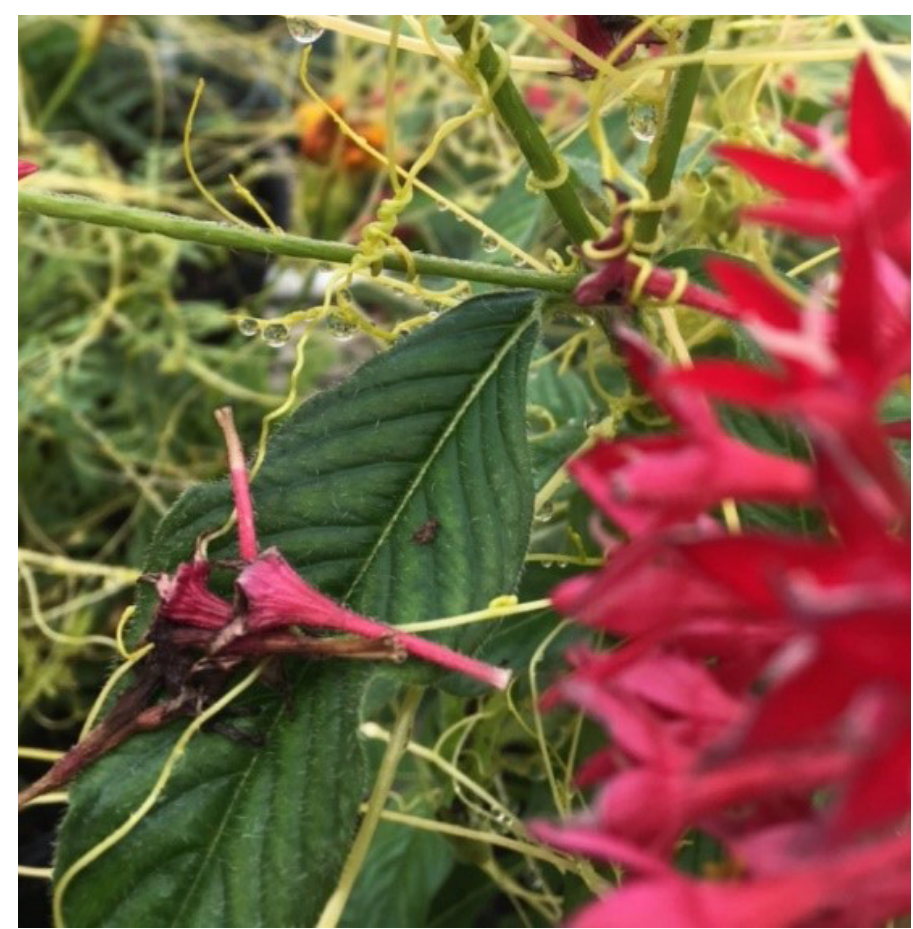

Figure 1. Dodder stems wrapping around pentas and forming multiple attachment points using haustoria.

Credits: Kaley Mierek, UF/IFAS

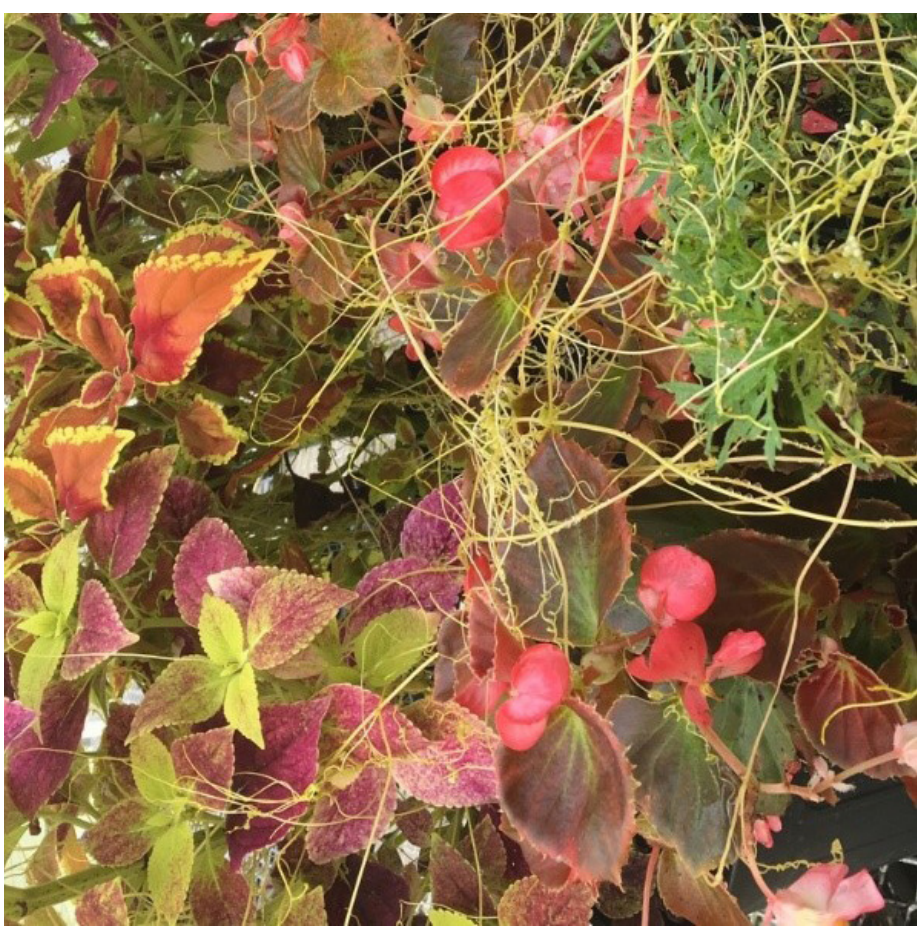

Figure 2. Dodder can spread vegetatively from one plant to another if the two host plants are close.

Credits: Kaley Mierek, UF/IFAS

\section{Seedling}

Seedlings are thin, twining, leafless, and vary in color from orange to yellow (Ashigh \& Marquez, 2010) (Figure 3).

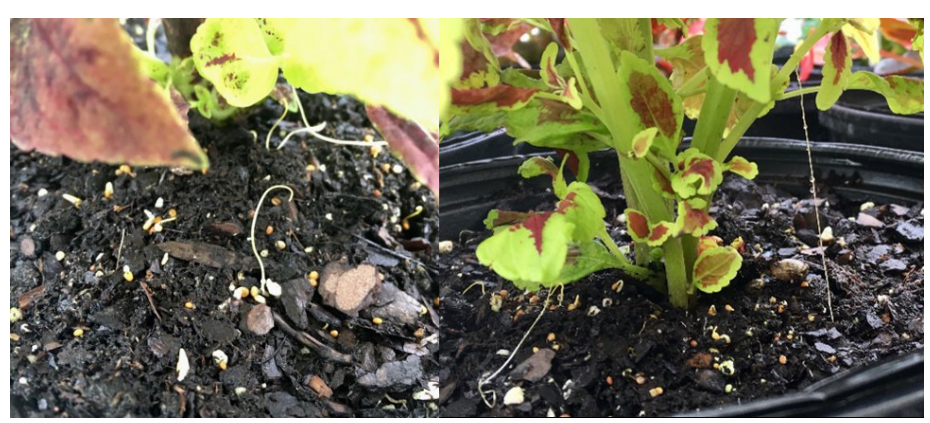

Figure 3. Dodder seedlings emerging (left) and beginning to attach to a coleus plant.

Credits: Kaley Mierek, UF/IFAS

\section{Shoot}

The stems of dodder are very thin. As the plant matures, it may become a golden yellow or remain a yellowish-green color. Dodder produces very little to no chlorophyll and relies upon its host for water and nutrients. The portion of the stem that was connected to the soil degrades as the vine migrates up the host plant, eventually being free of the soil and reattaching itself to the host plant completely to the host plant (Figure 4) (Ashigh \& Marquez, 2010).

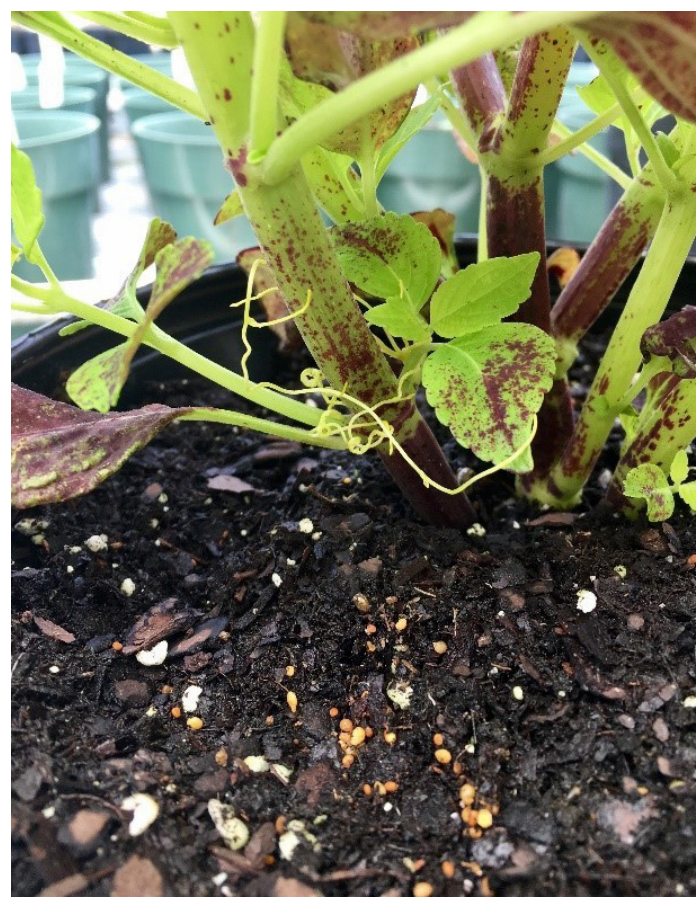

Figure 4. Once dodder has attached itself to a host plant, its connection to the soil withers away and it becomes completely reliant upon the host for survival.

Credits: Kaley Mierek, UF/IFAS

\section{Roots (Haustoria)}

Dodder has no true roots. In order to attach to a host plant, dodder plants form specialized structures called "haustoria" that invade the vascular tissues of host plants and allow the dodder plant to utilize nutrients and water from the host plant (Kaiser, Vogg, Furst, \& Albert, 2015). 


\section{Inflorescence}

Flowers are small, bell-shaped, and range from yellow to white. They emerge in clusters from summer to fall. Each flower produces one to four seeds.

\section{Fruit and Seeds}

Dodder produces small, pea-shaped fruit. Seeds can vary in size depending on the species, but are typically $1 / 16$ of an inch and are light- to medium-brown in color. Seeds can remain viable in the soil for more than 10 years, and, as a result, it is important to remove plants prior to seed production.

\section{Similar Species}

Leafless swallow-wort (Cynanchum scoparium) can sometimes be mistaken for dodder because it is also a thread-like vine that experiences leaf loss with age. Leafless swallowwort vines are typically thicker than dodder and are green. Love vine (Cassytha filiformis) (Figure 5) is a parasitic plant found in Florida that can easily be mistaken for dodder. The primary difference is that love vine tends to climb and parasitize large woody plants and shrubs, whereas dodder tends to spread closer to the ground on herbaceous plants (Nelson, 2008).

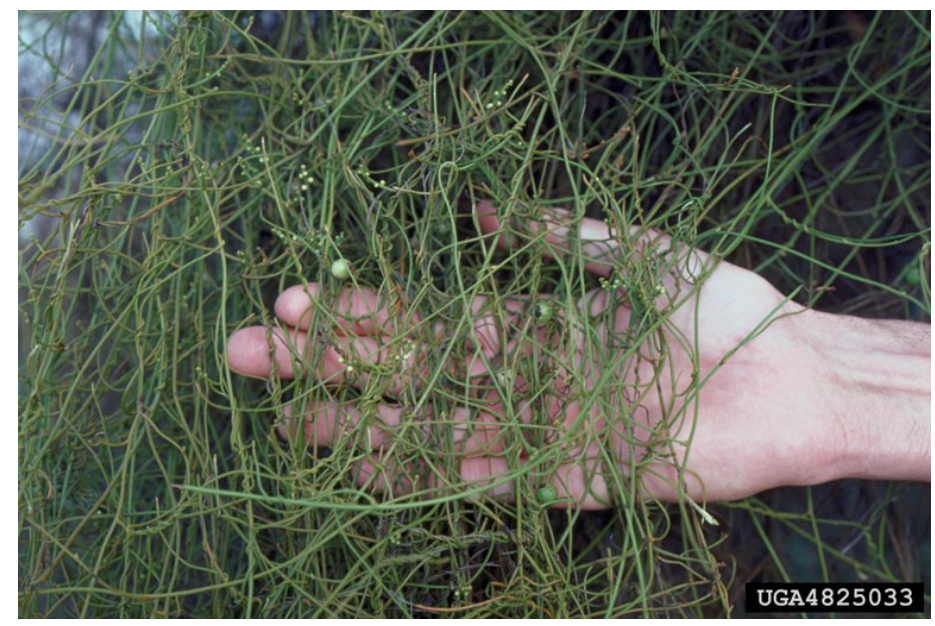

Figure 5. Love vine (Cassytha filiformis) is also a parasitic weed common in landscapes and is similar in appearance to dodder. Credits: Edward L. Barnard, Florida Department of Agriculture and Consumer Services

\section{Plant Biology}

Dodder plants depend on their host for survival, but seeds germinate independently of host plants. Germination can be variable depending upon dodder species, but will generally be highest during spring and summer months, as overwintering may be needed to break seed dormancy. Research on C. campestris showed highest levels of germination occur at temperatures of 85 to $90^{\circ} \mathrm{F}$. Flowering and seed production can occur in the late spring throughout fall. Although dodder is a summer annual, many species have the ability to over-winter within host tissues (as haustoria) and regrow the following spring (Hutchinson \& Ashton, 1980; Sandler, 2010).

Impacts to the host plant can vary depending on the host species and its stage of development when the infestation occurs. Seedlings and young plants will be much more susceptible than established plants. Dodder does not usually kill its host, but death can occur in severe cases. Plant growth will also be reduced, and dodder causes obvious aesthetic issues in ornamental settings. Infestations can also stress host plants, making them more susceptible to disease and insect damage.

\section{Management Physical and Cultural Control}

Prevention and sanitation is the best control option for this species. Clean equipment thoroughly if it has been used in infested areas. In nursery and greenhouse situations, remove and destroy the host plant once it is infested with dodder. Inspect liners and new plant shipments to ensure that none of the plants entering the production facility are infested. Hand removal is typically not effective because dodder can regrow from small stem fragments left behind. It is also important to scout regularly to ensure that dodder has not infested weeds or other plants growing in non-crop areas. Cuscuta species (other than native species) are both Florida and federal noxious weeds, meaning that it is unlawful to introduce, multiply, possess, move, or release any living state of the plant (including seeds). Nursery crops can be quarantined if this weed is found on inventory.

In the landscape, small infestations may be controlled by hand weeding, but this is rarely effective. It is usually more effective to remove the host and the dodder simultaneously. If only a small portion of a plant is infested, pruning the host below the point of attachment can be an effective management option, but may result in disfiguring the ornamental. In areas where dodder is problematic, planting non-host plants can reduce dodder infestations. Most monocotyledonous species (e.g., flax lily, mondo grass, liriope, and ornamental grass species) are not susceptible to dodder infestations. Research at North Carolina State University has shown that certain annual bedding plants, including scaevola, verbena, gomphrena, and sweet potato (Ipomoea spp.), are not preferred hosts of dodder, while petunias and snapdragons are more susceptible (Neal, 2006). 


\section{Chemical Control}

Dinitroanline herbicides, including prodiamine (Barricade), pendimethalin (Pendulum), Treflan (trifluralin), and other products containing these active ingredients

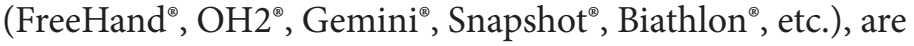
recommended for preemergence control. Once dodder has infested an ornamental, there are no selective herbicides offering control without harming the ornamental host. Postemergence herbicides, including pelargonic acid (Scythe), diquat (Reward), and other contact herbicides, are recommended if the host plant can be damaged or killed. Contact herbicides are not translocated, meaning that thorough spray coverage is needed for control. While these herbicides are not translocated, they will cause considerable injury or death to many ornamental plants, especially herbaceous species. In situations where dodder is pervasive, removal of the infested host and prevention of subsequent infestation with the use of preemergence herbicides is recommended. Removal of adjacent host plants that could serve as a "bridge" and the use of other sanitation and preventative measures are also recommended. For more information on controlling weeds in ornamentals, please see Postemergent Herbicides for Use in Ornamentals.

\section{Acknowledgements}

This EDIS publication was funded in part by the 2017 Microbiology and Cell Science Summer Undergraduate Research Program funded by the USDA REEU grant (Broadening the STEM Pipeline with Research Experiences in Agricultural Science; \#2017-67032-26012).

\section{Disclaimer}

Mention of a commercial or herbicide brand name or chemical does not constitute a recommendation or warranty of the product by the authors or the University of Florida, Institute of Food and Agricultural Sciences, nor does it imply its approval to the exclusion of other products that may also be suitable. Products should be used according to label instructions and safety equipment required on the label and by federal or state law should be employed. Pesticide registrations may change so it is the responsibility of the user to ascertain if a pesticide is registered by the appropriate state and federal agencies for its intended use.

\section{References}

Ashigh, J., and E. E. Marquez. 2010. "Dodder (Cuscuta spp.) biology and management." NMSU: New Mexico State University Guide A-615. Accessed 13 June 2017. http://aces. nmsu.edu/pubs/_a/A615/welcome.html.
Goss, W.L. 1924. The vitality of buried seed. U.S. Dept. Agric. Bull. No. 83. 26 pp.

Holm, L., J. Doll, E. Holm, J. Panch, and J. Herberger. 1997. World Weeds: Natural Histories and Distribution. John Wiley \& Sons, New York. 1129 pp.

Hutchison, J.M. and F.M. Ashton. 1980. "Germination of field dodder (Cuscuta campestris).” Weed Sci. 28:330-333.

Kaiser, B., G. Vogg, U.B. Furst, and M. Albert. 2015. "Parasitic plants of the genus Cuscuta and their interaction with susceptible and resistant host plants." Frontiers in Plnt. Sci. doi:0.3389/fpls.2015.00045.

Lanini, W.T. and M. Kogan. 2005. "Biology and management of Cuscuta in crops." Cien. Inv. Agr. 32:127-141.

Lanini, W.T., D.W. Cudney, G. Miyao, and K.J. Hembree. 2010. "How to manage pests." Accessed 13 June 2017. http://ipm.ucanr.edu/PMG/PESTNOTES/pn7496.html.

Neal, J.C. 2006. "Bedding plant host preference for dodder." South. Nurs. Assoc. Res. Conf. 51:411-412.

Nelson, S.C. 2008. "Cassytha filiformis." https://www.ctahr. hawaii.edu/oc/freepubs/pdf/PD-42.pdf. Accessed 29 June 2017.

Sandler, H.A. 2010. "Managing Cuscuta gronovii (swamp dodder) in cranberry requires an integrated approach." Sustainability 2:660-683.

Wunderlin, R.P., A.R. Franck, and F.B. Essig. 2007. "Atlas of Florida plants." Accessed 29 June 2017. http://florida. plantatlas.usf.edu. 